\title{
Biopsychosocial Approaches in Primary Care
}

State of the Art and Challenges for the 21 st Century 


\title{
Biopsychosocial Approaches in Primary Care
}

State of the Art and Challenges for the 21 st Century

\author{
Edited by \\ Hoyle Leigh \\ University of California, San Francisco \\ Fresno, California
}




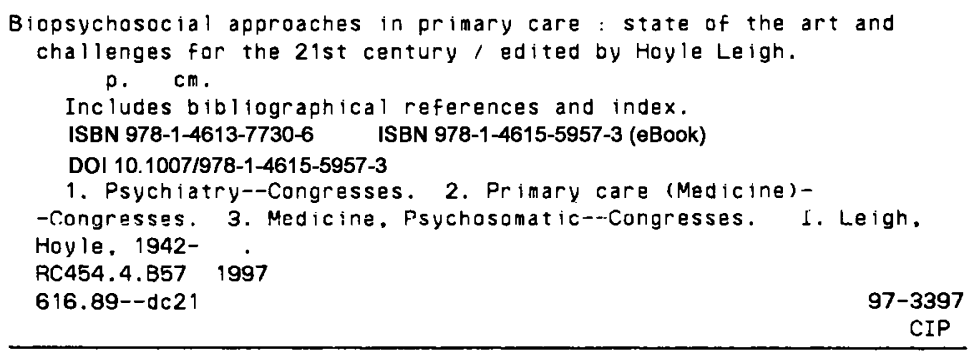

Based on proceedings of the 13th World Congress of the International College of Psychosomatic Medicine, held September 10-15, 1995, in Jerusalem, Israel

ISBN 978-1-4613-7730-6

C1997 Springer Science+Business Media New York

Originally published by Plenum Press, New York in 1997

Softcover reprint of the hardcover 1st edition 1997

\section{All rights reserved}

No part of this book may be reproduced, stored in a retrieval system, or transmitted in any form or by any means, electronic, mechanical, photocopying, microfilming, recording, or otherwise, without written permission from the Publisher 
FOR VINNIE AND ALEXANDER 


\section{$\mathrm{P}_{\text {Rerace }}$}

What will the legacy of the 20th century be to medicine? For the first time in human history, genetic and molecular mechanisms of pathogenesis as well as demonstrably effective treatments of many diseases have been discovered. Early in this century, X-ray made it possible to look into the human body; now with CT and MRI we can even look at slices of the body without cutting it. These and other exciting developments in medical technology ushered in an explosion of knowledge in the biomedical sciences. With technology came superspecialization and fragmentation in patient care. The primary concern of the superspecialist was often the diseased tissue or organ rather than the patient as a person. The biopsychosocial model (as an alternative to the biomedical model) was proposed by George Engel in mid-century as an attempt to restore an appreciation of the psychological and social aspects of the patient in the pathogenesis and treatment of disease.

The biopsychosocial model, at its best, embodies an ideal of medical practice. A skilled biopsychosocial physician would be somewhat like the old-fashioned family doctor, who knows the patient, his/her family, occupation, subculture, as well as the patient's coping style. He/she would ask the patient about ongoing problems, recent stresses, and the impact of the illness on the family and workplace. The physician would, then, take all these factors into consideration in recommending and implementing state of the art treatment. Although this type of comprehensive evaluation and treatment may be more time consuming than a purely problem-oriented focused examination, the reimbursement for a comprehensive evaluation in a fee-for-service environment would partially compensate for the time spent. The satisfaction of providing state-of-the-art service may make up the difference.

Though there are numerous theoretical and practical problems in the biopsychosocial model (these problems are discussed in some detail in this book), the major threat to this ideal comes from the managed care environment, the epidemic that is fundamentally transforming the practice of medicine. At its worst, managed care, with its preoccupation with efficiency and cost-containment, forces the physician to focus on the single presenting complaint, and to ameliorate it least expensively in the shortest amount of time. Why ask about stresses that will surely take more of the physician's time, and possibly lead to more expensive tests for other stress-related diseases? At its best, however, managed care may encourage biopsychosocially directed prevention and early treatment of disease. As early detection and treatment of depression and anxiety reduce the overall health care cost of the patients, managed care systems should welcome primary physicians who can perform a competent biopsychosocial evaluation of a patient efficiently, and then proceed either to treat the patient directly, or to make judicious referrals. 
This book is intended to show the primary care physicians, and psychiatrists who work with primary physicians, that it is possible to provide state-of-the-art biopsychosocial care to patients efficiently, even in a managed care setting. Part I of this book, State of the Art, therefore, presents succinct discussions of the psychiatric syndromes often encountered in the primary care setting, and how the primary care physician might evaluate and treat them effectively and efficiently. Another purpose of the book is to take stock of the theoretical aspects of the biopsychosocial model, and to stimulate a discussion among our colleagues about how best to preserve our ideal of comprehensive care into the 21 st century. Part II, Challenges for the 21st Century, presents theoretical and conceptual chapters on some of the many remaining tasks for medicine if it is to maintain what is best of the biopsychosocial model. Symposia presented at the13th World Congress of the International College of Psychosomatic Medicine, held in Jerusalem, in 1994, provided the nidus for this volume, but this book is far more than just proceedings of the conference. Many contributors to this volume did not attend the conference, and all the presentations have been updated and rewritten. (Please see Introduction for further discussion of the contents of the book).

This book is for primary care physicians, medical students, and mental health workers who work closely with primary care physicians. It is also for psychiatrists and students of philosophy of medicine, and, especially, for administrators of health care organizations (who I hope will gain an insight into the necessity and efficiency of a biopsychosocial approach).

I am grateful to my colleagues and students who have provided me with ideas and feedback to my presentations, lectures, and writings. I am also grateful to Ms. Eileen Bermingham and Mr. Robert Wheeler at Plenum Press for their assistance in preparing and producing this book. 


\section{CONTENTS}

Introduction: Medicine in a Changing Universe at the Threshold of the $21^{\text {st }}$ Century .......................... 1

H. Leigh

\section{Part I. State of the Art}

Chapter 1. Psychiatric Diagnosis in Primary Care:

The Biopsychosocial Perspective

T.N. Wise

Chapter 2. Biopsychosocial Approaches to Anxiety in Primary Care .......... 19

H. Leigh

Chapter 3. Biopsychosocial Approaches to Depression in Primary Care

H. Leigh

Chapter 4. Psychiatry in the Primary Care Setting: Managing Chronic Illness:

Psychiatric Issues

S. Beck and L. Tong

Chapter 5. Factitious Physical Disorders in the Managed Care Setting

S. J. Eisendrath

Chapter 6. Chronic Pain

J. Streltzer

Chapter 7. Biopsychosocial Approaches to Mental Disorders in the Elderly

I. Ahmed and J. Takeshita

Chapter 8. Aggressive Nutritional Program for the Institutionalized Alzheimer's

Patient

V.M. Leigh, A. Knudsen, M.S. Franklin, A. Rauch, and S. Leiby

Chapter 9. The Expanded Biopsychosocial Model in Child Psychiatry

D.A. Fox 
Part II. Challenges for the $21^{\text {st }}$ Century

Chapter 10. From Biopsychosocial Model to Patientology

H. Leigh

Chapter 11. Teaching Psychiatry to Primary Care Physicians

D.R. Lipsitt

Chapter 12. Psychosomatic Thinking as Reflected in Practice and Teaching of Primary Health Care - Introducing the Salutogenic Approach.. 159 B. Maoz and W. Schüffel

Chapter 13. Reductionism Revisited: Return of the Biomedical Model 179

A.A. Howsepian

Chapter 14. Religion and Spirituality in the Primary Care Setting:

Toward the $21^{\text {st }}$ Century

S. Waldfogel

Chapter 15. A Biopsychosocial Critique of Managed Mental Health Care and Its Relation to Primary Care

S.W. Robbins

Contributors 235

Index 239 